\title{
PENGARUH PEMASARAN INTERNAL DAN KUALITAS LAYANAN INTERNAL TERHADAP KEPUASAN PELANGGAN INTERNAL (STUDI PADA INDUSTRI KEPARIWISATAAN DI DAERAH ISTIMEWA YOGYAKARTA)
}

\author{
Jumadi \\ Mahasiswa Program Doktor Ilmu Manajemen UNPAD \\ Dosen Fakultas Ekonomi Universitas Widya Mataram Yogyakarta \\ jmd.mataram@gmail.com
}

\begin{abstract}
The aim of this research is to investigate the implication of internal marketing and internal service quality effectivity towards internal customer satisfaction in Tourism Industry in Yogyakarta Special Territory. This internal marketing studyinvolves variables of motivation and reward system, effective communication, effective employee's selection, effective recruitment, effective development, effective support system, and healthy work environment. While the internal quality service aspects that will be examined in this study are: tangible, emphaty, responsiveness, reliability and assurance, and then their influences on internal customer satisfaction would be analyzed.The sample size is 210 respondents, which is determined usingpurposive sampling method. The main instrument for data collection in this study isthrough questionnaire. The analysis tool used to examine the hypothesis of the study is Structural Equation Modeling using AMOS Version 20.0 Software. The result of the study shows that: Internal marketing and internal quality service significantly influence internal customers satisfation. However, the internal quality service influence the internal customers satisfaction more significantly. Therefore the managers in tourism industry should improve the internal marketing more than the internal quality service.
\end{abstract}

Keywords:internal marketing, internal quality service, internal costumer satisfaction.

\section{PENDAHULUAN}

Pariwisata merupakan salah satu industri raksasa dunia yang mendorong pertumbuhan sektor ekonomi paling cepat. Dilihat dari perkembangan kunjungan wisatawan internasional dalam dua dasawarsa tahun 1990 sampai dengan 2009 sektor ini mengalami pertumbuhan kunjungan wisatawan dunia mencapai dua kali lipat. Pada tahun 1990 jumlah wisatawan internasional tercatat 438 juta maka pada 
tahun 2009 tercatat sebanyak 880 juta wisatawan internasional (UNWTO 2010). Menurut Boz (2011), bahwa pariwisata merupakan salah satu sektor industri yang berkembang pesat mulai awal abad 21 digunakan sebagai ukuran yang reliabel terhadap pertumbuhan ekonomi dan negara yang sedang berkembang. Berdasarkan T dan TCI (2011) bahwa Indonesia pada tahun 2011 menempati ranking 74 Travel and Tourism Competitive Index tingkat dunia yang meningkat peringkatnya dari ranking 81 pada tahun 2009 dan menduduki ranking 13 pada tahun 2011 di tingkat Asia Pasifik.

Salah satu tempat tujuan wisata utama di Indonesia adalah Daerah Istimewa Yogyakarta (DIY). DIY sebagai salah satu tempat tujuan wisata utama di Indonesia dituntut untuk semakin sadar wisata dan menerapkan Sapta Pesona, menjaga dan meningkatkan kepedulian terhadap kelestarian lingkungan. Sehingga sektor ini mampu memberikan kontribusi yang besar terhadap Pendapatan Asli Daerah (PAD). Namun berdasarkan data Badan Pusat Statistik (BPS) DIY (2011) bahwa PAD DIY berasal dari sektor industri kepariwisataan mengalami fluktuasi, hal ini disebabkan karena penurunan pertumbuhan kunjungan wisatawan.Penurunan pertumbuhan kunjungan wisata ke DIY disebabkan oleh pertama, adanya pergeseran minat kunjungan ke Bali, Lombok dan Bandung, hal ini dikarenakan tujuan wisata tersebut menawarkan paket yang lebih murah dibandingkan DIY (Himna 2013;http://travel.kompas.com);kedua, disinyalir kurang optimalnya program pemasaran pariwisata yang belum melibatkan pada stakeholer terkait dalam pembuatan perencanaan pemasaran pariwisata.

Dalam rangka meningkatkan pertumbuhan dan kunjungan kembali wisatawan dan keberlanjutan pariwisata DIY perlu suatu program pemasaran pariwisata yang terpadu (integrated marketing tourism). Menurut Kumar (2010)konsep pemasaran terpadu merupakan konsep perusahaan yang berorientasi pada konsumen, kepuasan pelanggandan tindakan manajemen yang terpadu serta realisasi tujuan organisasi dengan baik. Salah satu elemen dalam pemasaran terpadu adalah pemasaran internal (internal marketing).

Pemasaran Internal (Internal Marketing/IM) merupakan pendekatan yang relatif baru yang diadopsi oleh perusahaan dalam rangka meningkatkan kualitas produk dan layanan dalam mencapai tingkatan kinerja yang lebih baik. Perusahaan melihat kegiatan operasi internal merupakan hal yang penting, terutama pemahaman tentang sumber daya manusia perusahaan. Menurut ELSamen dan Alshurideh (2012) menyatakan bahwa sebuah perubahan dengan pola pikir baru telah muncul dengan perusahaan yang menjadikan karyawan sebagai pelanggan, mereka harus diberikan layanan yang berkualitas untuk memastikan keberhasilan bisnis.

Menurut Cai (2010) seperti yang didukung oleh Susana (2012) bahwa pelanggan internal merupakan individu departemen lain dalam organisasi yang dilayani oleh pemasokinternal. Hal tersebut menunjukkan bahwa suatu organisasi 
terdiri dari rantai unit individu, yang dihubungkan bersama-sama, selanjutnya unit terkait digunakan untuk memuaskan pelanggan eksternal. Bersamaan dengan hal tersebut kesadaran pelanggan baik ekternal maupun internal terhadap kualitas merupakan hal terpenting, pada kondisi tersebut organisasi dituntut untuk meningkatkan segala aspek kualitas.

Menurut Lombard (2010) menjelaskan bahwa keberhasilan penerapan prinsip-prinsip pemasaran internal (internal marketing) merupakan prasyarat untuk pemasaran eksternal yang efektif. Kegiatan pemasaran selalu berujung kepada usaha dalam memberikan kepuasan pelanggan (Jumadi 2012). Perusahaan mempunyai dua pelanggan yaitu pelanggan internal (karyawan) dan pelanggan eksternal (konsumen) yang senantiasa harus mendapat perhatian dan pelayanan yang baik.Penilaian program pemasaran internal (internal marketing), digunakan untuk mengetahui pandangan karyawan (pelanggan internal) terhadap perlakuan perusahaan yang mereka terima. Upaya ini membantu manajer untuk menemukan apa saja yang perlu perbaikan untuk dianalisis lebih lanjut. Beberapa penelitian yang terkaitdengan pemasaran internal antara lain, penelitian yang dilakukan oleh Hers (2010) yang menyatakan bahwa kepuasan pelanggan eksternal dapat dicapai melalui kepuasan pelanggan internal. Aburoub dan Hers (2011) yang menjelaskan dalam penelitiannya bahwa internal marketing mempunyai pengaruh positif terhadap kinerja perusahaan, demikian juga dengan Eldeen dan El-Said(2011) yang menyimpulkan bahwa organisasi telah menerapkan internal marketingdengan baik dan berdampak terhadap perusahaan.

Hasil penelitian ELSamen and Alshurideh (2012) yang menggunakan dimensi pemasaran internal (internal marketing) dan dimensi kualitas layanan internal, (internal quality service) diperoleh kesimpulan bahwa ada hubungan antara dimensi internal marketingdengan dimensi kualitas layanan internal (internal quality service). Hal ini juga didukung oleh hasil penelitian dari Wang et al.(2012) yang menyatakan bahwa internal marketing yang mencakup efektifitas kegiatan pelatihan terhadap karyawan berpengaruh terhadap kepuasan pelanggan.

Oleh karena itu, penelitian ini bertujuan untuk menyelidiki implikasi efektifitas pemasaran internal dan kualitas layanan internal terhadap kepuasan pelanggan internal pada industri kepariwisataan di DIY.Berdasarkan latar belakang tersebut diatas maka yang menjadi permasalahan dalam penelitian ini adalah sebagai berikut.

1. Bagaimana pengaruh pemasaran internal dan kualitas layanan internal terhadap kepuasan pelanggan internal?

2. Variabel apakah yang paling berpengaruh terhadap kepuasan pelanggan internal? 


\section{KERANGKA TEORITIS DAN PENGEMBANGAN HIPOTESIS}

\section{Pemasaran Internal (Internal Marketing)}

Pasar internal (internal market) menurut Gronroos (1994) merupakan karyawan yang termotivasi serta kinerjanya berorientasi pada pelanggan. Oleh karena itu, untuk dapat melakukan aktivitas pemasaran internal dengan baik mempunyai karyawan yang bermental baik dan termotivasi merupakan syarat keberhasilannya. Menurut Ballantyne (2004) menjelaskan bahwa tujuan dari kegiatan pemasaran internal adalah untuk meningkatkan kualitas hubungan dengan pemasaran eksternal. Pemasaran internal merupakan aspek yang sangat penting terhadap kegiatan pemasaran jasa, perusahaan jasa memilih orang yang tepat untuk mengerjakan pekerjaan yang tepat dan membangun karyawan yang berorientasi kepada pelanggan. Pemasaran internal (internal market) menjadi engsel yang berasumsikan bahwa kepuasan karyawan dan kepuasan pelanggan akan saling berhubungan dan kemudian membuat internal marketing sebagai awal untuk kegiatan external marketing(Kumar 2010).

Menurut Mishra (2010) menjelaskan bahwa tujuan dari internal marketingadalah untuk mendapatkan motivasi dan kesadaran konsumen atau karyawan dalam mencapai layanan yang unggul. Internal marketing menurut Araoub dan Hersh (2011) digunakan untuk merujuk kepada kegiatan dalam organisasi yang carryout dalam rangka untuk menarik dan memenangkan hati dan pikiran karyawan dalam memberikan layanan yang dapat membedakan dengan layanan dari organisasi lainnya. Sementara itu pemasaran internal menurut Kotler dan Keller (2012) merupakan unsur pemasaran holistik yang termasuk didalamnya meliputi tugas perekrutan, pelatihan dan motivasi karyawan yang mampu untuk melayani pelanggan dengan baik. Hal ini memastikan bahwa setiap orang dalam organisasi dapat melaksanakan prinsip-prinsip pemasaran yang tepat terutama manajer senior. Kegiatan pemasaran dalam perusahaan bisa sama pentingnya dengan kegiatan yang ada di luar perusahaan.

Berdasarkan hal tersebut bahwa internal marketing adalah aktifitas pelayanan yang diberikan kepada pelanggan internal (interal customer) dengan harapan tercipta kepuasan pelanggan internal, untuk dapat memberikan kepuasan pada pelanggan eksternal. Oleh karena itu, langkah awal yang dapat di tempuh adalah memberikan kepuasan kepada pelanggan internal dengan memperhatikan dimensi pemasaran internal.

Penelitian Hallowell et al. (1996) Internal Service Quality, Customer and Job Satisfaction: Linkages and Implications for Management. Tujuan penelitian Hallowell et al. (1996) untuk mengetahui hubungan Internal Servis Quality, Servis Capability and Customer Satisfaction. Berdasarkan hasil Penelitian Hallowell etal.(1996) peroleh informasi bahwa terdapat hubungan antara internal quality service dengan service capability dan kepuasan pelanggan namun internal quality 
servismempunyai hubungan yang lebih kuat terhadap kepuasan kerja dibandingkan dengan kepuasan pelanggan (Hallowell etal., 1996: 26).

Penelitian Eraqi (2006) tentang Tourism Services Quality (TourServQual) in Egypt The Viewpoints of External and Internal Customers, bertujuan untuk mengevaluasi pandangan konsumen terhadap kualitas pariwisata di Egypt.Penelitian yang dilakukan dengan menggunakan duasurvey yaitu; terhadap internal customer satisfaction dan survey terhadap external customer satisfcation. Berdasarkan hasil penelitian Eraqi (2006) bahwa hanya 28 persen dari 500 responden internal customer yang puas hal ini berarti bahwa kepuasan pelanggan internal tidak dapat digunakan sebagai ukuran kualitas. Namun berdasarkan penelitian Eraqi (2006) bahwa pelanggan eksternal puas terhadap layanan kepariwisataan.

Menurut Hersh(2010) yang dalam penelitiannya Evaluate the impact of Tourism Services Quality on customer's satisfaction, tujuan penelitian adalah untuk mengivestigasi dampak kualitas layanan kepariwisataan terhadap kepuasan, dengan menggunakan dua juga jenis sampelyaitu internal customer sama seperti yang dilakukan oleh Eraqi (2006) dengan jumlah sampel sebanyak 500 karyawan dan external customer atau wisatawan dengan jumlah sampel sebanyak 700 wisatawan. Berdasarkan hasil penelitiannya ditemukan bahwa internal marketing belum mendukung kualitas layanan kepariwisataan di Jordan, untuk itu dalam meningkatkan kualitas layanan dalam bidang kepariwisataan, Hersh (2010) menyarankan diperlukannya tiga syarat yaitu: internal marketing (internal customer satisfaction), external customer satisfaction dan efficient process.

Tujuan dari penelitian Eldeen dan El-Said(2011) dengan judul Implementation of Internal marketing on a sample of Egyptian five-star Hotelsadalah untuk membuat konsep akademik dalam membangun instrumen pengukuran kinerja. Hasil penelitiannya yang dilakuan di hotel berbintang lima di Mesir tersebut didapatkan hasil bahwa organisasi telah menerapkan internal marketingdan karyawan menyetujui penerapan program tersebut.

Penelitian ELSamenet al. (2012) tentang The Impact of Internal Marketing on Internal Service Quality: A Case Study in a Jordanian Pharmaceutical Company. Tujuan dari penelitian tersebut adalah untuk menguji pengaruh internal marketing terhadap internal quality service. Berdasarkan hasil penelitiannya diperoleh hasil bahwa internal marketing yang terdiri motivation and reward system dapat meningkatkan kinerja dan signifikan mempengaruhi kualitas layanan terutama terhadap dimensi tangible, assurance dan responsiveness.Effective employee's selection berpengaruh positif terhadap dimensi kualitas layanan internal terutama terhadap dimensi emphaty, recruitment berpengaruh terhadap kualitas layanan internal yang mencakup; tangible, reliability, resonsiveness, assurance dan emphaty.

Efektifitas pengembangan (effective development) berpengaruh terhadap kualitas layanan internal (internal quality service). Effective support system 
berpengaruh terhadap kualitas layanan internal (internal quality service). Namun,healthy work environment dan internal communication tidak berpengaruh terhadap kualitas layanan internal (internal quality service).

\section{Internal Service Quality}

Mengacu pada Schneider dan White (2004) bahwa untuk memastikan karyawan memberikan layanan yang berkualitas, layanan perlu provided dengan alat yang diperlukan oleh sumber daya. Menurut Jain dan Gupta (2004) menyebutkan bahwa kualitas layanan telah diakui sebagai alat strategis untuk mencapai efisiensi operasional dan meningkatkan kinerja bisnis. Kualitas layanan internal memiliki dampak langsung terhadap kepuasan karyawan dan sebaliknya. Jika kualitas layanan internal rendah, sehingga adalah kepuasan karyawan juga akan rendah. Di sisi lain, jika karyawan mempunyai kepuasan yang tinggi, hal ini disebabkan karena adanya kualitas layanan internal yang baik (Susana2012).

Layanan internal merupakan layanan yang disediakan antar departemen yang berbeda dalam organisasi (Susana 2012). Penelitian Wang dan Lee (2012) tentang The Mediating Effect of Quality of Service on the Effectiveness of Employee Training and Customer Satisfaction, bertujuan untuk mengetahui mediasi antara kualitas layanan efektifitas pelatihan karyawan terhadap kepuasan pelanggan. Penelitian Wang dan Lee (2012) sampel yang digunakan adalah sebanyak 200 karyawan dan 200 pelanggan. Dimensi yang digunakan dalam variabel pelatihan karyawan adalah reacting, learning and behaving sedangkan dimensi kualitas layanan yang digunakan adalah; tangible, reliability, reacting, guarantee and emphaty, sedangkan indikator yang digunakan dalam variabel kepuasan adalah product value, service and environment.

Berdasarkan hasil penelitian Wang dan Lee (2012) ditemukan bahwa terdapat hubungan yang positif antara efektifitas pelatihan karyawan dengan kualitas layanan, terdapat hubungan yang positif antara kualitas layanan dengan kepuasan pelanggan, terdapat hubungan yang positif antara efektifitas pelatihan karyawan dengan kepuasan pelanggan, tetapi hubungan antara efektifitas pelatihan karyawan terhadap kepuasan pelanggan hubungannya lebih rendah, jika dibandingkan hubungan antara efektifitas pelatihan karyawan dengan kepuasan pelanggan dan hubungan kualitas layanan dengan kepuasan pelanggan, hal ini berarti kepuasan pelanggan lebih besar diperoleh melalui kualitas layanan.

Ada kesamaan dimensi antara penelitian ELSamen dan Alshurideh(2012) dengan penelitian olehEldeendan El-Said(2011) persamaanya tersebut adalah Implementation of a Reward and Recognition System, demikian juga ada antarakesamaan penelitian antara Eraqi (2006) danMohammad Hersh(2010) baik variabel maupun industri yang diteliti. Oleh karena itu, variabel dalam internal marketing dari penelitian Eraqi (2006), Hersh (2010), Eldeen dan El-Said (2011), 
model ELSamendan Alshurideh (2012) serta penelitian Wang dan Lee (2012) digunakan untuk mengelaborari dalam penelitian ini.

\section{Internal Customer}

Menurut Susana(2012) menyatakan bahwa pelanggan internal adalah sebagai individu dalam departemen lain yang ada dalam organisasi yang dilayani oleh pemasok internal. Suatu organisasi terdiri dari rantai unit individu, yang dihubungkan bersama. Selanjutnya, unit terkait yang ada digunakan untuk memuaskan pelanggan eksternal (Cai 2010) dalam (Susana2012), sebuah sinonim untuk pemasok internal adalah penyedia layanan internal. Karena pelanggan internal dan pemasok internal membentuk rantai kerja sama dari masing-masing employee dalam efek rantai untuk kemampuan untuk memenuhi atau melebihi exsternal customers perusahaan.

Menurut ELSamen and Alshurideh (2012) mendefinisikan bahwa pelanggan internal sebagai setiap anggota (karyawan) dari organisasi penerima layanan dan produk dari anggota organisasi dalam melaksanakan pekerjaannya. Organisasi besar, mempunyai tantangan untuk mencapai tingkat komunikasi yang memuaskan menjadi lebih tinggi. Lebih banyak orang berinteraksi satu dengan yang lainnya dapat menyebabkan situasi di mana pesan yang sama dapat berasal dari beberapa jalur komunikasi. Selain itu, ketika berusaha untuk meningkatkan tingkat layanan yang tinggi, komunikasi dengan rekan dapat pula menimbulkan nilai yang tak terduga (Susana2012).

\section{Kepuasan Pelanggan}

Oliver (1997) menyatakan bahawa kepuasan pelanggan merupakan responkonsumen terhadappenilaian fiturproduk atau jasa, atau produk ataulayanan itu sendiri, yang disediakan(atau menyediakan) tingkatpemenuhan yang menyenangkan atau tidak menyenangkan terkait dengan konsumsi. Sementara itu Oliver (1999), menjelaskan bahwa kepuasan pelanggan adalah respon pemenuhan pelanggan untuk layanan.

Menurut Heskett dan Sasser (1997) mengemukakan bahwa people merupakan faktor yang berperan penting dalam organisasi. Dalam organisasi jasa kepariwisataan unsur people bukan hanya memainkan peran penting dalam bidang operasi saja namun juga dapat berperan dalam melakukan hubungan atau kotak langsung dengan konsumen. Sumber-sumber kepuasan pelanggan dan ketidakpuasan pelanggan pada setiap interaksi penyampaian jasa yaitu: recovery, respon terhadap kegagalan penyampaian jasa, adaptability, antisipasi dan penyesuaian terhadap kebutuhan pelayanan, spontanity, memberikan sesuatu yang mengesankan dan tidak terduga sebagai bentuk kompensasi kegagalan dan coping, kemampuan mengelola situasi (Zeithmalet al., 2006). 
Berdasarkan beberapa hasil penelitian tersebut diatas dapat disimpulkan bahwa internal marketing berpengaruh terhadap kinerja dan kualitas layanan internal, hal ini penting bagi perusahaan untuk mengoptimalkan program internal marketing. Oleh karena itu dalam mewujudkan kepuasan pelanggan eksternal maka sebaiknya kepuasan pelanggan internal menjadi kunci untuk kepuasan pelanggan eksternal.

Berdasarkan argumentasi di atas, maka dapat dinyatakan hipotesis sebagai berikut.

H1: Pemasaran internal dan kualitas layanan internal berpengaruh terhadap kepuasan pelanggan internal.

H2: Pemasaran internal lebih berpengaruh terhadap kepuasan pelanggan internal.

\section{Kerangka Pemikiran}

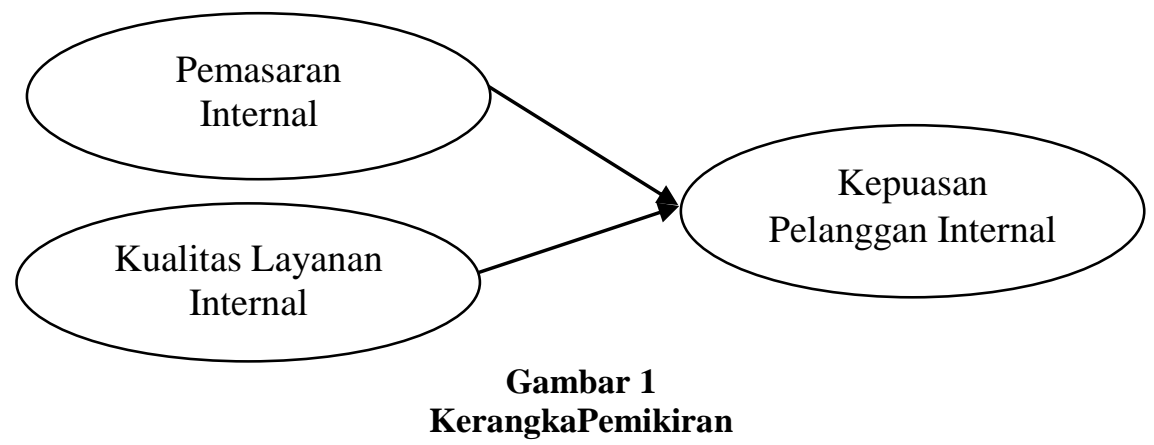

\section{METODA PENELITIAN}

Penelitian ini merupakan penelitian explanatorysurvey yangmenguji pengaruh antara variabel bebas pemasaran internal dan kualitas layanan internal denganvariabel terikatnya kepuasan pelanggan internal.

\section{Populasi dan Sampel}

Populasi penelitian ini adalah karyawan yang bekerja pada objek wisata di Daerah Istimewa Yogyakarta (DIY)termasuk karyawan dinas pariwisata di DIY,karena keterbatasan maka tidak semua populasi diteliti, sehingga penelitian ini menggunakan sampel. Penentuan sampel dilakukan melalui tehnique porpusive sampling dengan tujuan untuk mendapatkan data yang representative dengan ketentuan karyawan bekerja sekurang-kurangnya satu tahun. Sampel ditetapkan minimal lima sampai dengan sepuluh kaliparameter (Hair 1998) sehingga ditetapkan sebanyak 210 responden.

\section{Teknik Pengumpulan data}

Pengumpulan data tentang persepsi karyawan yang bekerja di objek wisata dan dinas pariwisata di DIY melalui: 
1. observasi, yaitu dengan melakukan pengamatan langsung ke lapangan, menelaah mengkaji tentang permasalahan yang sedang dikaji;

2. penyebaran kuesioner kepada karyawan bekerja pada obyek wisata di DIY dan dinas pariwisata, dengan desain kuesioner skala lima.

\section{Analisis Data}

Pengujian hipotesis dilakukan dengan menggunakan Structural Equation Model(SEM) dengan pengolah data digunakan bantuan program AMOS versi 20 dengan hubungan variabel sebagai berikut:

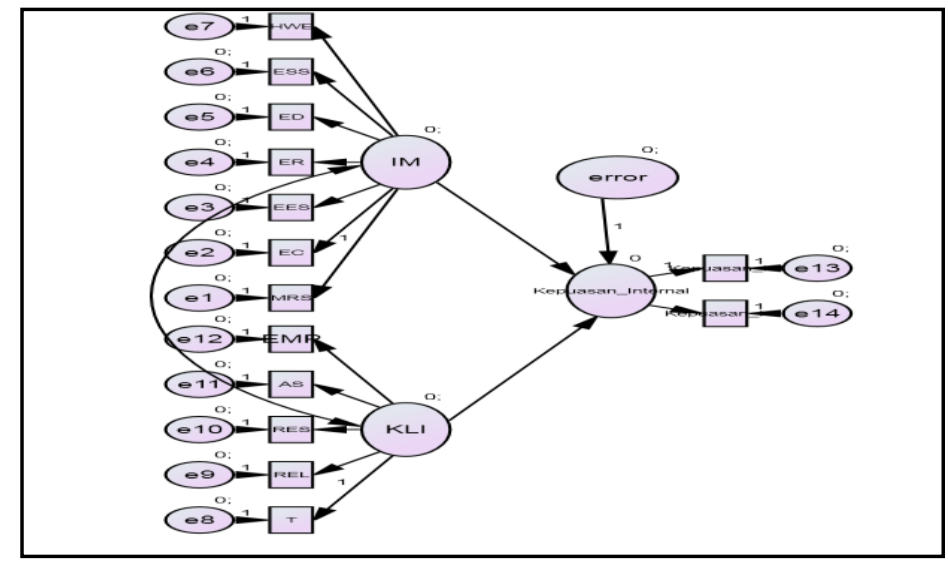

Gambar 2

Model Penelitian

Berdasarkan gambar tersebut maka persamaan strukturalnya sebagai berikut:

$$
\eta_{1}=\gamma_{1.1} \xi_{1}+\gamma_{1.2} \xi_{2}+\zeta_{1}
$$

Keteragan:

$\xi_{1}=$ Variabel Pemasaran Internal

$\xi_{2}=$ Variabel Kualitas Layanan Internal

$\eta_{1}=$ Variabel Kepuasan Karyawan

\section{HASIL PENELITIAN}

\section{Analisis Full Structural Equation Model}

Berdasarkan hasil evaluasi atas asumsi SEM, analisis selanjutnya adalah evaluasi atas kesesuaian model dengan berbagai kriteria goodness-of-fit, seperti terlihat dalam Tabel 1.Berdasarkan Tabel 1 terlihat bahwa hasil evaluasi model untuk full model structural modification sudah menunjukkan kriteriayang baik dimana untuk setiap ukuran nilai goodness of fit yaitu CFI, NFI, TLI telah memenuhi kriteria.Sedangkan Cmin/DF dan RMSEA sudah mendekati kriteria yang diharapkan. Berdasarkan hal tersebut maka secara keseluruhan dapat disimpulkan bahwa model 
struktural telah dapat menghasilkan tingkat kebenaran pendugaan. Dengan demikian untuk melakukan pengujian terhadap hipotesis penelitian dapat dilakukan.

Tabel 1

Uji Kesesuaian Model

\begin{tabular}{lccc}
\hline \multicolumn{1}{c}{ Kriteria Acuan } & Nilai Acuan & Hasil & Arti \\
\hline Kai Kuadrat & Diharapkan & 4718,590 & - \\
& Kecil & & - \\
P Value & $>0,05$ & 0,000 & Baik \\
RMSEA & $<0,1$ & 0,14 & Cukup Baik \\
CMIN/df & $2-5$ & 5,3 & Baik \\
TLI & $\geq 0,9$ & 0,837 & Baik \\
CFI & $\geq 0,9$ & 0,867 & Baik \\
NFI & $\geq 0,9$ & 0,843 & \\
\hline
\end{tabular}

Sumber: Data Primer diolah 2014

\section{Hasil Uji Hipotesis}

Berdasarkan analisis data diperoleh hasil yang menunjukkan nilai CR yang identik dengan nilai t hitung pada hasil pengolahan dibandingkan dengan nilai ktitisnya yaitu $\pm 1,96$ pada tingkat significant 0,05 (5 persen) seperti terlihat pada Tabel 2 berikut ini.

Tabel 2

Hasil Estimasi Pengaruh Antar Variabel Berdasarkan Model SEM

\begin{tabular}{rlrrrr}
\hline Variabel Dependent & Variabel Independent & Estimate & S.E. & C.R. & P Value \\
\hline Kepuasan_Internal (X1) & Internal Marketing & 0,516 & 0,115 & 4,480 & 0,000 \\
Kepuasan_Internal (X2) & Kualitas Layanan Internal & 0,790 & 0,083 & 9,503 & 0,000 \\
\hline
\end{tabular}

Sumber: Data primer diolah 2014

Hasil analisis jalur untuk model awal berdasarkan gambar yang membentuk pola pengaruh antar variabel dapat dilihat pada Gambar 3 berikut ini.

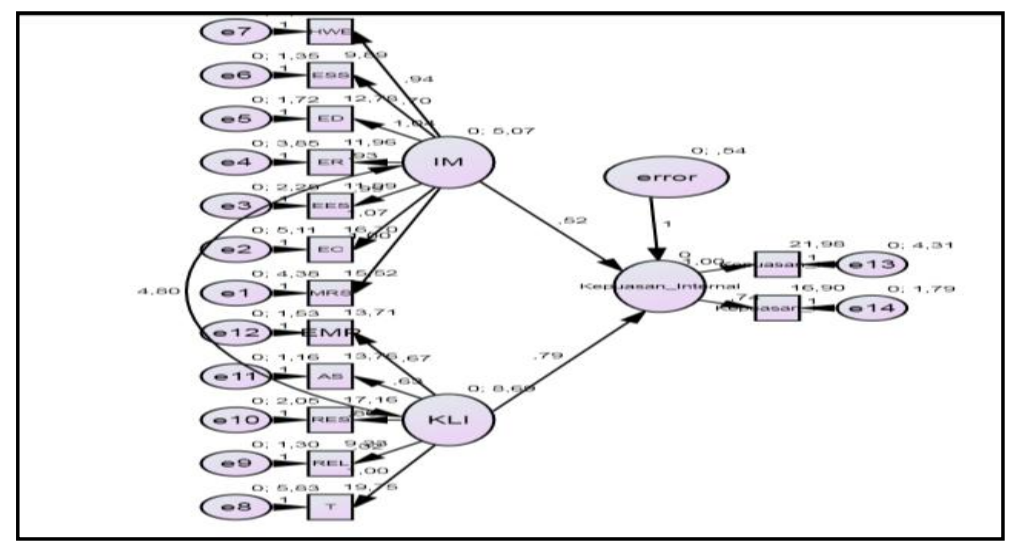

Gambar 3

Pengaruh antar Variabel 
Berdasarkan hasil estimasi menggunakan Structural Equation Model (SEM) AMOS diperoleh persamaan sebagai berikut:

$$
\eta_{1}=0,516 \xi_{1}+0,790 \xi_{2}+\mathrm{e}
$$

Keterangan:

Nilai $\mathbf{R}^{2}=0,952$

NilaiSquared Multiple Correlations adalah sebesar 0,952 hal ini menunjukkan bahwa kepuasan pelanggan internal dipengaruhi sebesar 95,2 persen oleh pemasaran internal dan kualitas layanan internal sedangkan sisanya sebesar 4,8 persen dipengaruhi oleh faktor lain diluar variabel penelitian ini.

Tabel 3

Hasil Pengujian Hipotesis

\begin{tabular}{|c|c|c|}
\hline & Hipotesis & Kesimpulan \\
\hline H1 & $\begin{array}{l}\text { Pemasaran Internal dan kualitas layanan internal } \\
\text { berpengaruh terhadap kepuasan pelanggan internal. }\end{array}$ & Didukung \\
\hline $\mathrm{H} 2$ & $\begin{array}{l}\text { Pemasaran Internal lebih berpengaruh terhadap } \\
\text { kepuasan pelanggan internal. }\end{array}$ & Tidak Didukung \\
\hline
\end{tabular}

\section{PEMBAHASAN}

\section{Pemasaran Internalberpengaruh terhadap Kepuasan Pelanggan Internal}

Pemasaran internal merupakan kegiatan yang dilakukan dalam rangka memotivasi, berkomunikasi, seleksi dan penarikan tenaga kerja serta penyediaan lingkungan kerja yang sehat untuk memberikan semangat dalam berkerja sehingga tercipta produktivitas. Berdasarkan analisis deskripsi statistik bahwa pemasaran internal mampu memberikan semangat kerja hal ini terbukti dari penilaian menunjukkan angka indeks yang tinggi.

Model empirik ini menguji hipotesis pengaruh pemasaran internal terhadap kepuasan pelanggan intenal. Studi ini adalah menguji terhadap hasil temuan dalam penelitian yang dilakukan olehELSamen and Alshurideh (2012) mengelompokkan pemasaran dalam perusahaan (internal marketing) menjadi beberapa dimensi yang mencakup; motivation and reward system, effective communication, effective employee's selection, effective recruitment, effective development, effective support systemdan healthy work environment. Hipotesis yang menyatakan bahwa pemasaran internal berpengaruh terhadap kepuasan pelanggan internal terbukti dalam penelitian ini. Hal ini dapat dilihat dari angka estimasi antara pemasaran internal dengan kepuasan pelanggan internal yang ditunjukkan oleh nilai: $(B)=0,516 \mathrm{SE}=0,115$ dan $\mathrm{CR}=4,480$ dan $p=0,000$. Artinya bahwa semakin kuat pemasaran internal dan kualitas layanan internal maka semakin tinggi tingkat kepuasan pelanggan internal.

Hasil penelitian ini tidak mendukung hasil penelitian yang dilakukan oleh Hersh (2010) yang menemukan bahwa pemasaran internalbelum mendukungkualitas 
layanan kepariwisataan untuk itu dalam meningkatkan kualitas layanan dalam bidang kepariwisataan.Hersh (2010) menyarankan diperlukannya tiga syarat yaitu: internal marketing, internal customer satisfaction, external customer satisfaction dan efficien process.

Dalam penelitian ini membuktikan bahwa kepuasan pelanggan internal dipengaruhi oleh pemasaran internal yang mencakup: indikator motivation and reward System (MRS), effective communication (EC), effective employee's selection (EES), effective recruitment (ER), effective development (ED), effective support system (ESS), healthy work environment (HWE) dan kualitas layanan internal yang mencakup unsur tangible (TANG), emphaty (EMP), responsivenes (RES), reliability (REL) dan assurance (AS).

Dalam industri kepariwisataan betapa pentingnya penerapan pelayanan yang baik karena dapat mendukung terhadap improvisasi dan rasa tanggung jawab terhadap pelanggan internal (karyawan) dan kebutuhan organisasi yang mncerminkan proses pencapaian tujuan organisasi. Disamping itu dapat pula menyumbang terhadap peningkatan efisiensi sumber daya manusia kepariwisataan dan membangun saling hubungan antar personil dan pelanggan secara positif dalam rangka meningkatkan keterlibatan para personil pada berbagai aktivitas organisasi.

Pengaruh pemasaran internal terhadap kepuasan pelanggan internal dalam industri pariwisata didasarkan kepada proses pemasaran internal dan kualitas layanan internal yang melibatkan interaksi antar karyawan sehingga kepuasan pelanggan internal terwujud. Proses pemasaran internal yang baik menumbuhkan motivasi dan mempercepat arus komunikasi dalam organisasi yang pada giliranya membuat kegiatan menjadi efektif.

\section{Kualitas Layanan InternalBerpengaruh terhadap Kepuasan Pelanggan Internal.}

Layanan internal merupakan layanan yang diberikan oleh pengelola kepada pelanggan internal (karyawan). Dimensi dalam layanan internal ini mencakup: Tangible, emphaty, responsiveness, reliability dan assurance. Model empirik ini menguji hipotesis tentang pengaruh kualitas layanan terhadap kepuasan pelanggan intenal. Hasil estimasi antara kualitas layanan internal dengan kepuasan pelanggan internal adalah; $(B)=0,790 \mathrm{SE}=0,083$ dan $\mathrm{CR}=9,503$ dan $p=0,000$. Artinya bahwa semakin kuat kualitas layanan internal maka semakin tinggi tingkat kepuasan pelanggan internal.

Hasil penelitian ini mendukung temuan penelitian yang dilakukan oleh Hallowell etal. (1996) diperoleh informasi bahwa terdapat hubungan antara internal quality service dengan service capability dan kepuasan pelanggan. Namun Hallowell et al. (1996) menjelaskan bahwa internal quality servis mempunyai hubungan yang lebih kuat terhadap kepuasan kerja dibandingkan dengan kepuasan pelanggan. Secara empiris penelitian ini juga mendukung hasil penelitian yang dilakukan oleh (Wang 
dan Lee 2012) yang menunjukkan bahwa terdapat hubungan yang positif antara efektifitas pelatihan karyawan dengan kualitas layanan, terdapat hubungan yang positif antara kualitas layanan dengan kepuasan pelanggan, terdapat hubungan yang positif antara efektifitas pelatihan karyawan dengan kepuasan pelanggan, tetapi hubungan antara efektifitas pelatihan karyawan terhadap kepuasan pelanggan hubungannya lebih rendah, jika dibandingkan hubungan antara efektifitas pelatihan karyawan dengan kepuasan pelanggan dan hubungan kualitas layanan dengan kepuasan pelanggan, hal ini berarti kepuasan pelanggan lebih besar diperoleh melalui kualitas layanan.

Dalam industri kepariwisataan penerapan pelayanan yang baik sangat diperlukan karena dapat mendukung improvisasi dan rasa tanggung jawab terhadap pelanggan internal (karyawan) dan kebutuhan organisasi yang mencerminkan proses pencapaian tujuan organisasi. Disamping itu dapat pula menyumbang terhadap peningkatan efisiensi sumber daya manusia kepariwisataan, dapat membangun hubungan antar personil dan pelanggan secara positif dalam rangka meningkatkan keterlibatan para personil pada berbagai aktivitas organisasi.

Pengaruh kualitas layanan internal terhadap kepuasan pelanggan internal dalam industri pariwisata didasarkan kepada proses layanan internal yang melibatkan interaksi antar karyawan sehingga kepuasan pelanggan internal terwujud. Proses pemasaran internal yang baik menumbuhkan motivasi dan mempercepat arus komunikasi dalam organisasi yang pada giliranya dapat membuat kegiatan menjadi efektif. Pelayanan internal dalam industri kepariwisataan tercermin dalam setiap tindakan karyawan yang cepat tanggap,ketaatan menenuhi janjinya, saling bersedia bertukar jam kerja. Kesemuanya itu merupakan ukuran terhadap kualitas layanan internal yang diberikan sehingga kesuksesan layanan internal akan terwujud.

Berdasarkan hasil uji hipotesis partial tersebut diatas bahwa kualitas layanan lebih besar pengaruhnya terhadap kepuasan pelanggan internal dibandingkan dengan internal marketing. Hal ini berarti bahwa kualitas layanan internal lebih dapat mendorong dalam menciptakan kepuasan pelanggan internal.

\section{SIMPULAN}

Kepuasan pelanggan internal dipengaruhi oleh pemasaran internal dan kualitas layanan internal. Kualitas layanan memberikan pengaruh yang lebih kuat dibandingkan pemasaran internal. Oleh karena itu, kualitas layanan mampu memberikan tingkat kepuasan pada pelanggan internal. Berdasarkan hasil penelitian tersebut temuan penelitian ini adalah mendukung penelitian yang dilakukan oleh Hallowell et al. (1996), Hersh (2010), ELSamen and Alshurideh (2012), Wang dan Lee (2012) tentang pemasaran internal. Pemasaran internal merupakan kegiatan pemasaran yang memfokuskan karyawan sebagai pelanggan internal, yang menjadikan kegiatan pemasaran internal dan kepuasan pelanggan internal 
sebagaikunci untuk kepuasan pelanggan eksternal. Organisasi harus melayani karyawan (pelanggan internal) dengan baik, apabila pelanggan internal dilayani dengan baik maka pelanggan internal puas sehingga bekerja dengan baik sehingga dampaknya adalah kinerja organisasi menjadi lebih baik. Kepuasan pelanggan internal dipengaruhi sebesar 95,2 persen oleh pemasaran internal dan kualitas layanan internal sedangkan sisanya sebesar 4,8 persen dipengaruhi oleh faktor lain diluar variabel dalam penelitian ini.

\section{Saran}

Berdasarkan hasil temuan penelitian ini adalah bahwa: (1)pengelola industri kepariwisataan di DIY dapat mendesain keputusan berdasarkan hubungan variabel yang memiliki substansi strategis yaitu kegiatan pemasaran internal dan kualitas layanan internal sebagai pijakan utama dalam memberikan kepuasan pelanggan internal; (2)meningkatkan efektivitas kegiatan pemasaran internal dan kualitas layanan internal dengan penekanan terhadap peningkatan efektivitas kegiatan pemasaran internal.

\section{DAFTAR PUSTAKA}

Ballantyne, D. 2004. A relationship meditiated theory of internal marketing. Swedish School of Economic Business Administration. Helsinki Filand.

Boz, M. 2010. Leakages and value added in international tourism revenues; tourism satellite account as a measurement method. International Journal of Business and Social Science Vol.2 No.24 (December).

Eldeen, A. T., danA. T. El-Said. 2011. Implementation of internal marketing on a sample of Egyptian five-star hotels. Anatolia-An International Journal of Tourism and Hospitality Research.Vol.22 No.2 (August): 153-167.

ELSamen, A. A., danM. Alshurideh. 2012. The impact of internal marketingon internal service quality: A case study in a Jordanian pharmaceutical company.International Journal of Business and Management. Vol.7 No.19. Published by Canadian Center of Science and Education.

Eraqi, M. I. 2006. Tourism services quality (TourServQual) in Egypt the viewpoints of external and internal customers.Benchmarking: An International Journal.Vol.13 No.4: 469-492.

Grönroos, C.1994. From marketing mix to relationship marketing: Towards a paradigm shift in marketing. Management Decision. Vol.32 No.2: 4-20.

Ghozali, I. 2011.Model Persamaan Struktural: Konsep dan Aplikasi dengan Program AMOS 21.0.Semarang: Bagian Penerbitan UNDIP. 
Hersh, M. A. 2010.Evaluate the impact of tourism services qualityon customer's satisfaction.Institute of Interdisciplinary Business Research IJCRB.

Hersh, A. A. S. 2011.Relationship between internal marketing and service quality with customers' satisfaction.International Journal of Marketing Studies. Vol.3 No.2.

Hallowell R., Schilesinger L. A., and Zornitsky J.1996. Internal service quality, customer and job satisfaction: Linkages and implications for management. Human Resource Planning. Vol.19 No.2: 20.

Heskett, J. L., W. E. Sasser, dan L. A. Schlesinger. 1997. The Service Profit Chain. New York: Free Press.

Jain S., danG. Gupta. 2004. Measuring service quality: SERVQUAL vs. SERVPERF Scales. Vikalpa.Vol.29 No.2:25-37.

Jumadi. 2012. Integrasi pemasaran pariwisata dalam mewujudkan kunjungan kembali wisatawan ke DIY. Prosiding Seminar Nasional FMI Manajemen FE UII Yogyakarta 72.

Kementerian Koordinator Bidang Perekonomian. 2011. Masterplan Percepatan dan Perluasan Pembangunan Ekonomi Indonesia2012-2025. Jakarta: Kementerian Koordinator Bidang Perekonomian.

Kotler, P., K. K. Lane. 2012.Marketing Management Pearson. Pearson edition.

Kumar, P. 2010. Marketing of Hospitality and Tourism Service.Tata McGraw Hill Education Private Limited, New Delhi.

Lombard, R. M. 2010. Employees as customers - An internal marketing studyof the Avis car rental group in South Africa.African Journal of Business Management Vol.4 No.4: 362-372.

Mishra, S.2010. Internal Marketing- A tool to harness employees' power in ervice organizations in India.International of Business Management. Vol.5 No.1: 185-193.

Oliver, R. L. 1997. Satisfaction: A Behavioral Perspective on the Consumer. New York: The McGraw-Hill Companies, Inc.

Oliver, R. L. 1999.Whence consumer loyalty.Journal ofMarketing. Vol.63 (Special Issue):33-44.

Payne, A., S. Halt, dan P. Frow. 2000. Integrating employee, customer and shareholder value through an enterprise performance model: an opportunity for financial services. The International Journal of Bank Marketing. Vol.18 No.6: 258-73.

Schneider, B., danS. A. White. 2004. Service quality: research perspectives. California: Sage Pub-lications. 
Susana, J. 2012. Developing the internal service quality in organisation Y. Business Management Bachelor's Thesis.Laurea University of Applied Sciences.

T\&TCI. 2011. The Travel \& Tourism Competitiveness Report World Economic Forum.

UNWTO. 2010. Tourism Highlights. Available at www.UNWTO.org/facts.

Wang, M. C. 2012. The mediating effect of quality of service on the effectiveness of employee training and customer satisfaction.International Research Journal of Finance and Economics. Issue 90.

http://travel.kompas.com 